\title{
Abundance and Diversity of Zooplankton Communities in the Littoral Waters of Al-Habbaniya Lake, Iraq
}

\author{
Adel Mashaan Rabee \\ Department of Biology, College of Science, University of Baghdad, Baghdad-Iraq. \\ E-mail: adelmashaan@yahoo.com.
}

\begin{abstract}
This study was carried out on littoral waters of Al-Habbaniya Lake to obtain baseline data on the biodiversity of zooplankton from May 2013 to March 2014 at four different study sites. Sixtyseven taxa of zooplankton were found in Al-Habbaniya Lake. of these, 46 belonging to rotifera, 13 to cladocera, and 8 to copepoda. Rotifera was the dominant group (69\%), followed by copepoda $(25 \%)$ and cladocera (6\%). The predominant spp were Keratella cochlearis, K.valga and Brachionus calyciflorus from rotifera, while Diaphanosoma brachyurum and Bosmina longirostris were the most dominant species from cladocera. Water temperature, dissolved oxygen and $\mathrm{pH}$ were the main environmental variables which influenced zooplankton abundance in the lake. ShannonWiener diversity index ranged from 0.7 (copepoda) to 2.8 (rotifera), species richness inex ranged from1 (copepod) to 4 (rotifera) and evenness index fluctuated between 0.60-0.84. This meant that the species were evenly distributed in all sites sampled. Based on these findings, it is concluded that the relatively high zooplankton species diversity in the Al-Habbaniya Lake is an indication that the ecosystem of this lake is characterized as a 'steady state' type.
\end{abstract}

Keywords: Al-Habbniyh Lake, Shannon's index, species richness, zooplankton.

\section{Introduction}

Zooplankton holds a central position in the food chain of most of the lakes and reservoirs and is highly sensitive to environmental variations which as a result bring changes in their abundance, species diversity or community composition [1].

They do not only form an integral part of the lentic community but also contribute significantly to the biological productivity of the freshwater ecosystem[2].Several studies have demonstrated a higher richness in zooplankton species in littoral zones, especially when these are colonized by aquatic macrophytes [3].

These organisms offer several advantages as indicators ofenvironmental quality in both lakes and rivers. As a group, they have worldwide distribution, species composition and community structure which are sensitive to changes inenvironmental conditions, nutrient enrichment and different levels of pollution [4]. Zooplankton are frequently used as biotic indicators of water quality in freshwater where community size and relationships among copepods, cladocerans, ostracods and rotifers provides valuable information on the existing physical and chemical conditions [5].
Various indices like richness, diversity and evenness can be calculated when the data on taxonomy of different zooplankton is available [6]. To management of zoo- plankton diversity requires understanding its current status and trends over space and time. Considering the large littoral area of Lake Al-Habbaniya and the lack of studies on the zooplankton community in this areat, the present study was desigend: to update the previous zooplankton species lists in the area and provide new insights into its ecology and to assess the distribution of zooplankton species in the littoral zones.

\section{Materials and Methods \\ Study site}

Al-Habbaniya Lake (has a surface ranged from 184 to $426 \mathrm{~km}^{2}$, maximal depth of $13 \mathrm{~m}$ and total volume of 3.3 billion $\mathrm{m}^{3}$ ) is fed by the Euphrates River, located at $22^{\circ} 36^{\prime}$ to $22^{\circ} 46^{\prime}$ north latitude and $89^{\circ} 40^{\prime}$ to $89^{\circ} 50^{\prime}$ east longitude. Differences in water level ranged from 3.1 to $9.4 \mathrm{~m}$. Water salinity was about $0.2 \%$ [7]. The bottom sediments were $40-50 \mathrm{~cm}$ thick in the deepest part. The bottom sediments were loamy over the whole area which had a low content of organic matter, additionally, gravel and clay were 
found in some places. Sampling sites were selected to represent the different littoral zones of the lake. Site 1 was situated in the eastern part of the lake. Site 2 (southern), site 3 ( western) and site 4 located in the northern part of the lake where water depth did not exceed $8 \mathrm{~m}$. The littoral zones of lake are shallow and overgrown by Potamogeton perfoliatus and $P$. pectinatus, especially in site 1.

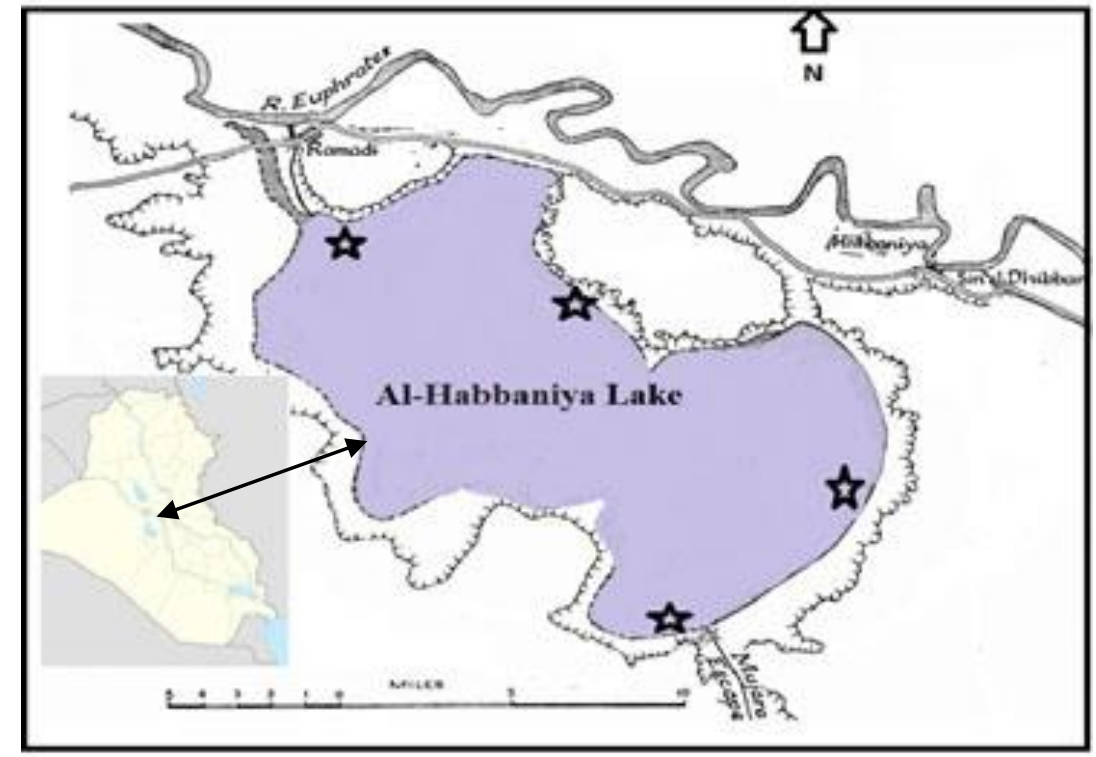

Fig.(1) Map of Al-Habbaniya Lake shows the location of sampling sites.

\section{Sampling design}

Samples of water and zooplankton were conducted bimonthly over anannual cycle (May 2013 to March 2014). Four sampling stations representing the different sites of the lake Fig.(1).

For physico-chemical analysis, air and water temperature were measured in the shade during the time of sampling using amercury thermometer graduated to $100^{\circ} \mathrm{C}$. Dissolved oxygen (DO), conductivity (EC) and $\mathrm{pH}$ were measured in situ by Lovibond Portable Multimeter Instrument; while total hardness was measured according to thestandard methods described by APHA [8].

\section{Zooplankton community structure}

At each site and on each sampling date, triplicate samples of 40L of water were taken with a 10-L bucket. Immediately after sampling, the water was poured through the $55 \mu \mathrm{m}$ plankton net. The collected organisms were preserved in the field using $4 \%$ formalin.

In the laboratory, Rose Bengal was added to the sample for easier organisms distinguishing from other suspended matter. Each quantitative sample was concentrated to $10 \mathrm{ml}$ and from this; $1 \mathrm{~mL}$ of sample was taken and all individual taxa present was counted by the Sedgwick rafter cell method. Identification of zooplankton was done under a microscope at different magnification with the help of keys provided by Edmondson [9] and Pennek [10].

Zooplankton abundance andoccurrence were computed and expressed as density (ind./L) andpercentage, respectively. The occurrence frequency of zooplankton species in the lake was analyzed using the occurrence constancy index $(S=n / N \times 100)$, i.e., the ratio between the number of samples in which a given species were found (n) to the total number of samples $(\mathrm{N})$ collected in the lake. Generally, this index enables determining the frequency occurrence of a given species on a four-point scale, i.e., absolutely constant species (AS) $->75 \%$, constant species (S) $51-75 \%$, accessory species (A) $-26-50 \%$, accidental species $(\mathrm{P})-<25 \%$ [11].

\section{Diversity indices}

In this study, three ecological indices were employed to estimate species diversity, Shannon-Wiener index $(\mathrm{H})$, species richness index (D), and species evenness index (E). 
Shannon-Wiener index $(\mathrm{H})$ : is a measure of species abundance and evenness and is expressed as:

\section{$\mathrm{H}=-\mathrm{ni} / \mathrm{N} \ln \mathrm{ni} / \mathrm{N}$}

Where (ni) are the number and biomass of one species, and $\mathrm{N}$ is the total number of individuals of all species [12].

We also used the species richness index $\mathrm{D}=(\mathrm{S}-1) / \log \mathrm{N}[13]$ :

Where $\mathrm{S}$ and $\mathrm{N}$ represent the number of species and the total number of individuals of all species, respectively.

Species equitability or evenness (E) is determined by the equation:

\section{$\mathrm{E}=\mathrm{H} / \mathrm{LnS}$}

Where $\mathrm{H}$ represents the Shannon-Wiener index values and $S$ is the number of species in samples [13].

\section{Statistical analysis}

Analysis of variance (ANOVA) was applied to the physical- chemical variables and densities of zooplankton in order to test differences among samples (temporal patterns) and sampling stations (spatial patterns). Significant (ANOVAs $\mathrm{P}<0.05$ ) were followed by post hoc (Tukey Honest [HSD]) tests were used to identify differences between station means. The correlation coefficient between different physico-chemical variables and the dominant zooplankton was carried out by SPSS software (version 12).

\section{Results and Discussion Physico-chemical variables}

The data on environmental parameters presented in Table 1 revealed wide variation. During the entire investigation period, the lake surface temperature fluctuated between 11 to $32^{\circ} \mathrm{C}$. The water temperature followed a seasonal pattern, with a maximum close to $32^{\circ} \mathrm{C}$ in July and a minimum below $11^{\circ} \mathrm{C}$ in January. The $\mathrm{pH}$ values ranged from 6.8 to 8.2 , a finding indicates an alkaline nature of lake water. Our analysis indicates that the higher pH value was recorded during July 2013, this alkalinity could be attributed to the low level of water and high photosynthesis rate of micro-macro organisms resulting in high production of free carbon dioxide during the equilibrium towards alkaline side. Al-Saadi
[14] stated that most Iraqi inland water reported as alkaline. According to Tanner et al., [15], the $\mathrm{pH}$ range between 6.0 and 8.5 indicates the medium productive nature of a reservoir; more than 8.5 highly productive and less than 6.0 low productive nature of a reservoir. In the case of Lake Al-Habbaniya, mean $\mathrm{pH}$ value observed during the study period was 7.5 reflecting a high production of zooplankton population. Large electrical conductivity oscillations were recorded in the study area, ranging from 400 to $1104 \mu \mathrm{Scm}^{-1}$ with high values recorded during July (summer); nevertheless, low values were noticed in the spring. Mean EC values were higher in summer. The conductivity variation can be an important regulator of the structure of zooplankton assemblages, especially species diversity and number of species.

Al-Habbaniya Lake was well aerated with dissolved oxygen values ranged from a minimum of $7 \mathrm{mg} / \mathrm{L}$ to a maximum of $12 \mathrm{mg} / \mathrm{L}$. The high value of hardness was recorded during winter, whereas low concentration was perceived during May with values varied from 250 to $610 \mathrm{mg} / \mathrm{L}$.

Remarkably, inter-station variation in physico-chemical variables did not significant between stations $(\mathrm{P}>0.05)$. There were, however, marked significantly $(\mathrm{P}<0.05)$ differences in the variables with the season. According to the results of the present study, the mainly physicochemical variables (water temperature, $\mathrm{DO}, \mathrm{pH}$ and $\mathrm{EC}$ ) of the study area were found to be suitable for life cycle of identified zooplankton population. 
Table (1)

Range, mean $\pm S D$ of physico-chemical variables at four sites of Al-Habbaniya Lake.

\begin{tabular}{|c|c||c||c||c||}
\hline $\begin{array}{c}\text { Physico-chemical } \\
\text { Parameters }\end{array}$ & Site 1 & Site 2 & Site 3 & Site 4 \\
\hline \hline Water temperature (C) & $11-30$ & $11.5-30$ & $12-31$ & $12-32$ \\
\hline \hline $\begin{array}{c}\text { Dissolved oxygen } \\
(\mathrm{mg} / \mathrm{L})\end{array}$ & $\begin{array}{c}7-11 \\
(9.4)^{\mathrm{a}} \pm 1.2\end{array}$ & $\begin{array}{c}8-12 \\
(9.7)^{\mathrm{a}} \pm 1.3\end{array}$ & $\begin{array}{c}8.5-12 \\
(9.7)^{\mathrm{a}} \pm 1.2\end{array}$ & $\begin{array}{c}7-12 \\
(9.6)^{\mathrm{a}} \pm 1.2\end{array}$ \\
\hline $\begin{array}{c}\text { Conductivity } \\
\left.(\mu \mathrm{S} \mathrm{cm})^{-1}\right)\end{array}$ & $\begin{array}{c}430-980 \\
(793)^{\mathrm{a}} \pm 79\end{array}$ & $\begin{array}{c}400-1104 \\
(790)^{\mathrm{a}} \pm 80\end{array}$ & $\begin{array}{c}450-900 \\
(780)^{\mathrm{a}} \pm 78\end{array}$ & $\begin{array}{c}400-1090 \\
(805)^{\mathrm{b}} \pm 85\end{array}$ \\
\hline \hline $\mathrm{pH}$ & $\begin{array}{c}6.8-7.9 \\
(7.4)^{\mathrm{a}} \pm 0.30\end{array}$ & $\begin{array}{c}6.9-8.2 \\
(7.5)^{\mathrm{a}} \pm 0.34\end{array}$ & $\begin{array}{c}6.9-8.2 \\
(7.5)^{\mathrm{a}} \pm 0.37\end{array}$ & $\begin{array}{c}6.9-8.2 \\
(7.5)^{\mathrm{a}} \pm 0.35\end{array}$ \\
\hline \hline $\begin{array}{c}\text { Total hardness } \\
(\mathrm{mg} / \mathrm{L})\end{array}$ & $293-610$ & $\begin{array}{c}270-582 \\
(399)^{\mathrm{b}} \pm 108\end{array}$ & $\begin{array}{c}250-580 \\
(389)^{\mathrm{a}} \pm 100\end{array}$ & $\begin{array}{c}280-590 \\
(376)^{\mathrm{b}} \pm 98\end{array}$ \\
\hline \hline
\end{tabular}

Note: Different superscript letters $(a$ and $b)$ in a row show significant differences $(P<0.05)$ indicated by Tukey Honest (HSD) significant difference tests, $S D=$ standard deviation.

\section{Zooplankton composition}

A total of 67 zooplankton taxa was identified in the Lake Al-Habbaniya Table (2). Rotifers showed the highest species richness (46 species), followed by cladocerans (13 species) and copepods (8 species). Rotifers were represented by 18 genera; the greatest richness was observed in the genus Brachionus (6 species) Cephalodella (5 species), Keratella (4 species) and Lecane (4 species). Nearly all of the taxa were euplanktonic. Among the rotifers, Keratella cochlearis, K. valga, Brachionus calyciflorus amphicerus (long spine), B. urceolaris, Polyarthera dolichoptera were the most constancy according to frequency index (Table (2)). Among Cladocera, Diaphanosoma brachyurum and Bosmina longirostris were recorded during all months. Copepoda were predominantly represented by Nauplii and copepodids (the developmental stages of Copepoda).

On the basis of quantitative study, rotifers were the most abundant of the 3 zooplankton groups comprising $69 \%$ of the total number of organisms, followed by the copepoda $(25 \%)$. The least abundant species belonged to the cladocera with $6 \%$. The maximum rotifers abundance was recorded during January (1300 ind./L) at site 2, while the lowest number was noted during May and July (300 ind./L). Overall, highest number of rotifers was found in winter, while the lower densities were recorded in summer (Figs. (2, 3, 4 and 5)). According to correlation coefficient, the electrical conductivity values showed negative correlation with rotifer density, while positive correlation with dissolved oxygen.

The greatest copepoda abundance (386 ind./L) was recorded site 1, while the lowest (119 ind./L) was recorded during May at site 3. Copepods nauplii accounted for $80 \%$ of the annual total density and, as mentioned above, reached their peak in March 2014. Also, the results showed a relative increase in densities of copepod and rotifer during July and September. The annual density of cladocera fluctuated between 20 to 80 ind./L with recorded peak densities in the summer. Except cladocera, one-way ANOVA revealed significant differences $(\mathrm{P}<0.05)$ between the number of zooplankton species present per site, moreover, significant differences were noted between the numbers of all major groups of zooplankton present per month $(\mathrm{P}<0.05)$. Zooplankton community was dominated by rotifers. Such dominance could be assigned to their short generation time and high reproductive rate [16]. The great contribution of rotifers to the species richness and abundance of the zooplankton community may be due the opportunistic features of this group [17] including their wide range of foods (from filamentous algae to bacteria) and high turnover rate, which makes it possible for them to colonize even unstable environments. Rotifers and small copepods are known to be more tolerant to adverse environmental conditions than the cladocerans. Rotifers density showed significant positive correlation with total hardness. Meshram [18] reported 
that calcium hardness is essential for normal growth and development of many aquatic ecosystems.

The decrease in the density of cladocera and copepoda in some months could have also been due to their lower ability to take advantage of the resource.

In the present study the copepod population shows positive correlation with temperature.

Webber et al., [19] commented that copepods are much more tolerant to high temperature and oxygen deficiency. Also, the peak in cladoceran species population during summer months showed the preference of this group towards the increasing temperature along with an increase in alkalinity and $\mathrm{pH}$. Increase in temperature has been associated with higher abundance and species diversity of zooplankton in aquatic ecosystems [20].

During summer, increasing temperature enhances the rate of decomposition due to which the water becomes nutrient rich similarly due to concentration followed by evaporation in summer season the nutrient concentration increases and abundant food present in the form of phytoplankton and micro-organism to zooplankton, while low density during the spring season attributed to heavy flood and fresh water inflow [21].

There are negative relationships between cladocera and rotifres. The negative relation between the presence of Daphina and rotifera has been well documented [22]. It has been observed that the populations of rotifers can be affected by cladocerans through the direct competition for shared resources. A strong negative relationship was found between densities of cladocera and copepoda with dissolved oxygen as obtained in the present study is attributed to low dissolved oxygen concentration during the month of summer which is the period for the maximum density of these groups.

The highest abundance of different groups of zooplankton in site 1 might be attributed to macrophyte vegetation. This observation coincided with Bozkurt and Guven [23] who stated that the abundance of cladocera in the vegetated areas was higher than unvegetated areas.

\section{Shannon-Weiner, species richness and species evenness indices}

Diversity index is commonly used as a biocriteria for the interpretation of the environmental status, as well as to measure the average degree of uncertainty within the community. The species diversity tends to be low in a stressed and polluted ecosystem [24]. A diversity index greater than 3 indicates clean water and values in the range of 1 to 3 is characteristic of moderately polluted conditions. Mason [25] pointed to that values less than 1 are characterizing heavily polluted conditions.

A summary of the total number of species, species richness indices, Shannon-Weiner indices and evenness indices are shown in Tables (3, 4, and 5). Shannon-Wiener diversity index of the log-transformed means of zooplankton species density for the study area showed different values during the study period for all sites. Regarding rotifera, Junuary registered the highest $\mathrm{H}$ value (2.8) followed by 2.5 in March. While the lowest value (1.2) was recorded in July. As annual mean, the highest value of $\mathrm{H}$ index (2.1) was recorded in site one (Table (3)). Shannon index of cladocera revealed slight spatial variations Table (4). When the index was monthly examined, it could be seen that Shannon index of cladocera ranged from 0.9 to 1.2 . It was at the maximum limit in July and minimum values in December through January.

For the same index, the maximum value of copepoda (1.3) was recorded in July suggesting higher faunal diversity and the least diversity (0.7) was recorded in May. Other months showed values intermediate between the two extremes.

Overall, the species richness indices and evenness followed the same trend at all months. The richness indices for rotifera in different months varied from 1.8 to 4 , while the evenness indices ranged from 0.6 to 0.8 . Evenness indices are concerned comparatively high values were found at sites 1 and 3, indicating that these two sites have much even distribution as compared to remaining sites. Values richness indices for cladocera ranged from a minimum of 1.4 to a maximum of 1.7. While the values of $\mathrm{E}$ indices for this group varied between 1.4-1.7 and 0.77-0.83. 
The biodiversity indices of copepoda varied from 1 to1.4 for species richness indices and fluctuated between 0.76 to 0.82 for evenness indices. There are significant differences among values obtained for both Shannonwiener diversity and species richness across months based on the results obtained using One Way ANOVA $(\mathrm{P}<0.05)$. While the statistical analysis saw no drastic change in species diversity for the 4 sampling sites.

However, variations in the indices may be considered to reflect the changes in the biomass. Shannon-Weinner index and species richness index recorded the highest values in site1 indicated the effect of high vegetation. Similar observations were recorded by MaiaBarbosa et al., [26] who mentioned that the highest diversity index of the crustacean community was found among submerged vegetation in summer. Diversity values of cladoceran community was found for the sites situated among submerged vegetation which create a favorable anti-predation refuge against a number of predators, both invertebrates and vertebrates [27].

The E index states that evenness is also a diversity index, which quantifies how equal the community is numerically and is a constraint between 0 and 1 [28].

High evenness indices were recorded in all sites during the study periods indicated that species are more evenly distributed in Al-Habbaniya Lake. This feature affirms equitable abundance of various species and concurs with the results of Rabee [29]. 
Table (2)

Species composition and occurrence constancy of zooplankton in the Al-Habbaniya Lake in relation to sampling sites, frequency of occurrence of a particular species on a four-degree scale: absolute constant species (AS - >75\%, constant species $(S)$ - 51-75\%, accessory species $(A)-26-$ $50 \%$ and accidental species $(P)-<25 \%$.

\begin{tabular}{|c|c|c|c|c|c|c|c|c|c|}
\hline Taxa. & $\begin{array}{c}\text { Site } \\
1 \\
\end{array}$ & $\begin{array}{c}\text { Site } \\
2 \\
\end{array}$ & $\begin{array}{c}\text { Site } \\
3 \\
\end{array}$ & $\begin{array}{c}\text { Site } \\
4 \\
\end{array}$ & Taxa. & $\begin{array}{l}\text { Sit } \\
\text { e } 1 \\
\end{array}$ & $\begin{array}{c}\text { Site } \\
2 \\
\end{array}$ & $\begin{array}{c}\text { Site } \\
3 \\
\end{array}$ & $\begin{array}{c}\text { Site } \\
4 \\
\end{array}$ \\
\hline \multicolumn{5}{|c|}{ Rotifera } & \multicolumn{5}{|c|}{ Rotifera } \\
\hline Asplanchna priodonta Gosse & A & - & $\mathrm{P}$ & - & $\begin{array}{l}\text { Polyarthera } \\
\text { dolichoptera Ide. }\end{array}$ & AS & $S$ & $S$ & AS \\
\hline Brachionus sp. & - & $\overline{\mathrm{P}}$ & 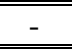 & $\bar{P}$ & P.euryptera & 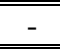 & $\overline{\mathrm{P}}$ & - & $\overline{\mathrm{A}}$ \\
\hline Brachionus angularis Gosse & $\mathrm{A}$ & $\mathrm{A}$ & A & $\mathrm{P}$ & P.vulgaris & $\mathrm{A}$ & $\mathrm{A}$ & $\mathrm{A}$ & $\mathrm{A}$ \\
\hline $\begin{array}{l}\text { B.calyciflorus } \\
\text { amphicerus(long spine) }\end{array}$ & AS & AS & $\mathrm{S}$ & AS & Pomopholyox sulcate & - & - & $\mathrm{P}$ & $\mathrm{p}$ \\
\hline B.leydigi Cohn & - & $\mathrm{A}$ & 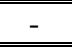 & $\mathrm{A}$ & Synchyta sp. & $\begin{array}{l}- \\
\end{array}$ & 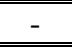 & $\mathrm{A}$ & $\mathrm{P}$ \\
\hline B.plicatilis Mull. & $\overline{\mathrm{A}}$ & $\overline{\mathrm{A}}$ & $\overline{\mathrm{A}}$ & $\overline{\mathrm{P}}$ & Synchyta oblonga & $\overline{\mathrm{A}}$ & 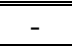 & $\overline{\mathrm{A}}$ & $\overline{\mathrm{A}}$ \\
\hline B.quadridentatas Hern. & $\mathrm{A}$ & $\mathrm{A}$ & $\mathrm{A}$ & 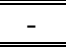 & Squtinella sp. & $\mathrm{A}$ & $\mathrm{A}$ & $\mathrm{A}$ & $\mathrm{A}$ \\
\hline B.urceolaris Mull. & $S$ & A & $S$ & AS & $\begin{array}{l}\text { Trichcerca similis } \\
\text { Wle. }\end{array}$ & A & A & A & - \\
\hline Cephalodella sp. & $\mathrm{P}$ & $\mathrm{P}$ & - & $\mathrm{P}$ & \multicolumn{5}{|c|}{ Cladocera } \\
\hline Cephalodella auriculata & $\mathrm{A}$ & - & $\mathrm{P}$ & AS & Alona sp. & $\mathrm{A}$ & - & $\mathrm{A}$ & - \\
\hline C.gibba & $\mathrm{A}$ & - & - & $\mathrm{A}$ & Alona guttata Sars & A & - & $\mathrm{A}$ & $\mathrm{A}$ \\
\hline C.intuta & A & $\mathrm{P}$ & A & A & $\begin{array}{l}\text { Bosmina longirostris } \\
\text { Mull. }\end{array}$ & $\mathrm{S}$ & AS & AS & AS \\
\hline C. mucronata & A & A & A & 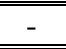 & B.coregoni Baird & A & A & 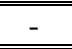 & - \\
\hline Colurella adriatica & A & A & - & $\mathrm{P}$ & $\begin{array}{l}\text { Cerodaphnia } \\
\text { reticulata Jur. }\end{array}$ & A & - & $\mathrm{S}$ & $\mathrm{P}$ \\
\hline Euchlanis delatata & $\mathrm{p}$ & $\mathrm{p}$ & $\mathrm{p}$ & - & $\begin{array}{l}\text { Ceriodaphnia rigaudi } \\
\text { Rich. }\end{array}$ & - & A & - & $\mathrm{P}$ \\
\hline Filinia longiseta Her. & - & $\mathrm{P}$ & - & $\mathrm{P}$ & $\begin{array}{l}\text { Chydorus spharicus } \\
\text { Mull. }\end{array}$ & A & A & - & A \\
\hline Hexarthera mira Hud. & - & - & $\mathrm{P}$ & & Daphnia sp. & - & - & $\mathrm{P}$ & $\mathrm{P}$ \\
\hline Epiphanus sp. & $\mathrm{A}$ & $\mathrm{A}$ & $\mathrm{A}$ & A & Daphnia galeata Sars & $\mathrm{A}$ & $\mathrm{A}$ & $\mathrm{A}$ & $\mathrm{A}$ \\
\hline Euchlanis deltata & $\mathrm{A}$ & A & $\mathrm{A}$ & $\overline{\mathrm{A}}$ & D. magna & $\begin{array}{l}- \\
\end{array}$ & 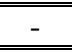 & 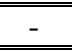 & $\begin{array}{l}- \\
\end{array}$ \\
\hline Filinia longiseta Her. & $\overline{\mathrm{A}}$ & A & $\overline{\mathrm{A}}$ & 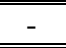 & D.leavis Birge & A & $\mathrm{A}$ & A & $\mathrm{AS}$ \\
\hline Hexarthera mira Hud. & A & A & - & $\mathrm{P}$ & $\begin{array}{l}\text { Diaphanosoma } \\
\text { brachyurum Lei. }\end{array}$ & $\mathrm{S}$ & $S$ & AS & $\mathrm{S}$ \\
\hline Keratella sp. & $\overline{\mathrm{P}}$ & A & $\bar{P}$ & $\bar{P}$ & Moina affinis Birge & A & A & A & $\begin{array}{l}- \\
\end{array}$ \\
\hline Keratella cochlearis Gosse & $\mathrm{AS}$ & $\mathrm{S}$ & $\mathrm{A}$ & $\mathrm{AS}$ & \multicolumn{5}{|c|}{ Copepoda } \\
\hline K.hiemalis Carl. & $\mathrm{P}$ & - & $\mathrm{AS}$ & A & Calanoida & & & & \\
\hline K.quadrata Mull. & $\overline{\mathrm{A}}$ & A & $\overline{\mathrm{A}}$ & $\overline{\mathrm{A}}$ & Diaptomus sp. & $\mathrm{A}$ & $\mathrm{AS}$ & $\mathrm{A}$ & $\mathrm{A}$ \\
\hline K.valga Her. & $\mathrm{AS}$ & A & $\mathrm{AS}$ & $\mathrm{S}$ & Cyclopoida & & & & \\
\hline Lecane sp. & A & $\overline{\mathrm{A}}$ & $\mathrm{A}$ & 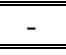 & Cyclop sp. & - & $\mathrm{A}$ & $P$ & - \\
\hline L.ludwigii & $\mathrm{P}$ & 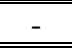 & $\mathrm{P}$ & $\mathrm{P}$ & Eucyclops. & $\mathrm{p}$ & $\mathrm{p}$ & 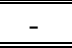 & $\mathrm{p}$ \\
\hline L.luna Mull. & $\mathrm{A}$ & $\mathrm{A}$ & $\mathrm{A}$ & $\mathrm{AS}$ & Halicyclop sp. & $\mathrm{A}$ & $\mathrm{A}$ & $\mathrm{A}$ & $\mathrm{A}$ \\
\hline Lepadella ovalis & $\mathrm{A}$ & $\mathrm{A}$ & $\mathrm{A}$ & A & Macrocyclop sp. & $\mathrm{A}$ & $\mathrm{A}$ & $\mathrm{A}$ & $\mathrm{P}$ \\
\hline L.patella & $\mathrm{P}$ & - & $\mathrm{P}$ & $\mathrm{P}$ & Paracyclop sp. & $\mathrm{P}$ & $\mathrm{P}$ & $\mathrm{P}$ & $\mathrm{P}$ \\
\hline Monostyla sp. & $\mathrm{P}$ & $\mathrm{P}$ & - & $\mathrm{P}$ & Harpacticoida & & & & \\
\hline Monostyla bulla Her. & $\mathrm{A}$ & $\mathrm{A}$ & $\mathrm{A}$ & $\mathrm{S}$ & Nitocra sp. & $\mathrm{A}$ & $\mathrm{A}$ & - & - \\
\hline M.clostercerca & $\mathrm{A}$ & $\mathrm{A}$ & $\mathrm{P}$ & $\mathrm{A}$ & Copepoda nauplii & $\mathrm{AS}$ & $\mathrm{AS}$ & $\mathrm{AS}$ & $\mathrm{AS}$ \\
\hline M.lunaris & $\mathrm{P}$ & $\mathrm{P}$ & $\mathrm{P}$ & - & & & & & \\
\hline Notholca acuminata Her. & $\mathrm{A}$ & A & $\mathrm{A}$ & $\mathrm{A}$ & & & & & \\
\hline N.labis & - & - & $\mathrm{P}$ & $\mathrm{P}$ & & & & & \\
\hline Philodina roseola & $\mathrm{P}$ & - & 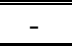 & $\mathrm{P}$ & & & & & \\
\hline
\end{tabular}




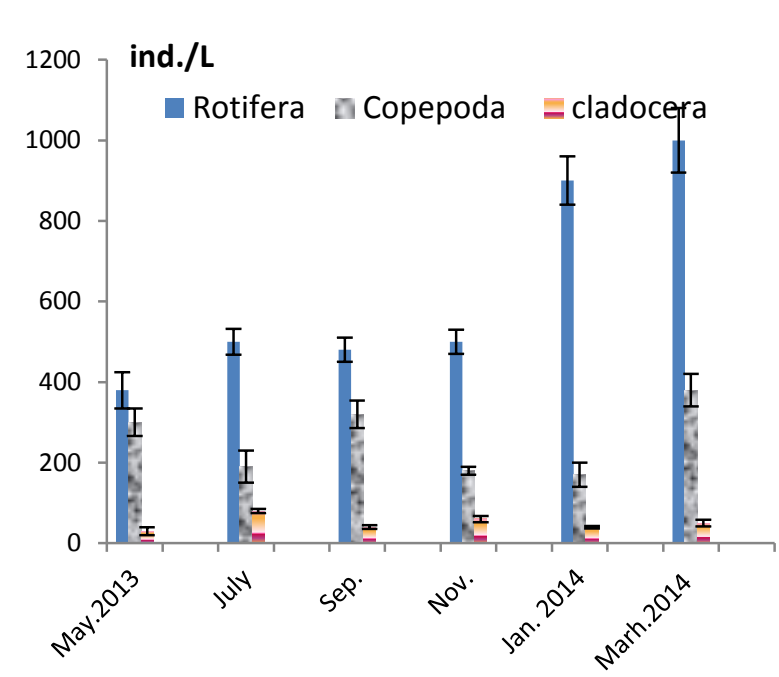

Fig.(2) Bimonthly variation (mean $\pm S D$ ) in the zooplankton densities at site 1.

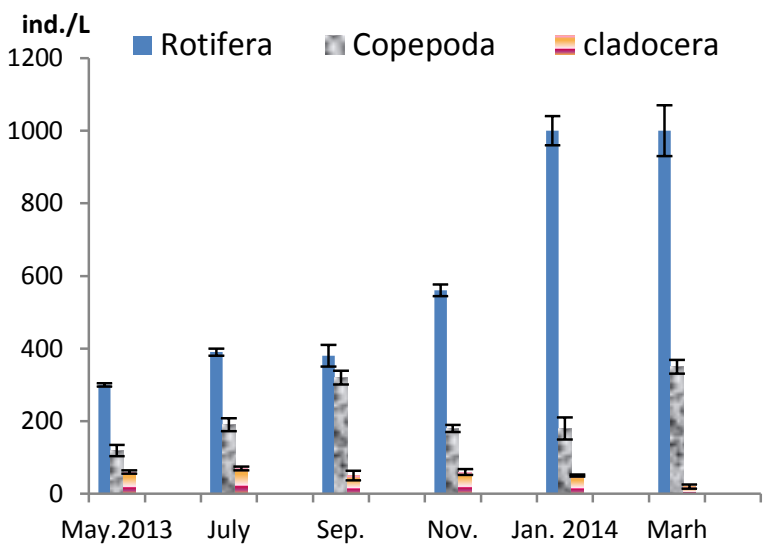

Fig. (4) Bimonthly variation(mean $\pm S D$ in the zooplankton densities at site 3.

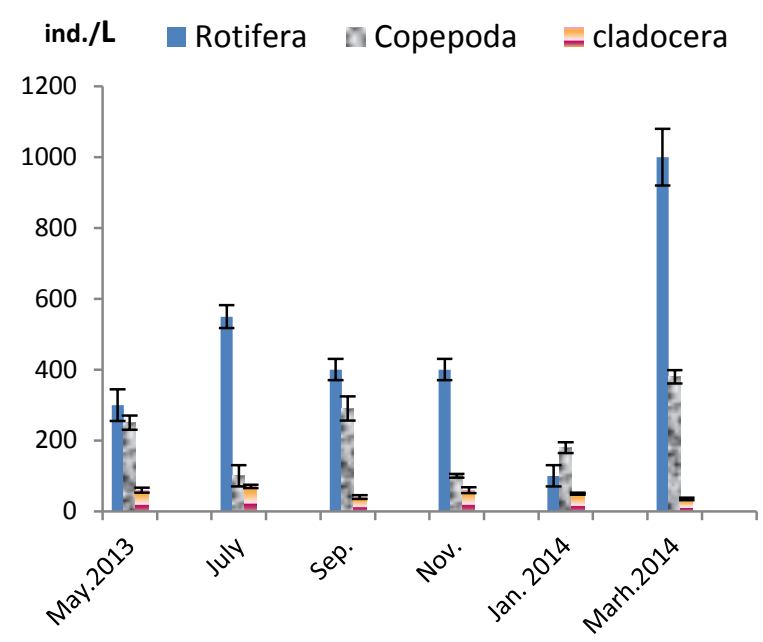

Fig. (3) Bimonthly variation (mean $\pm S D$ ) in the zooplankton densities at site 2.

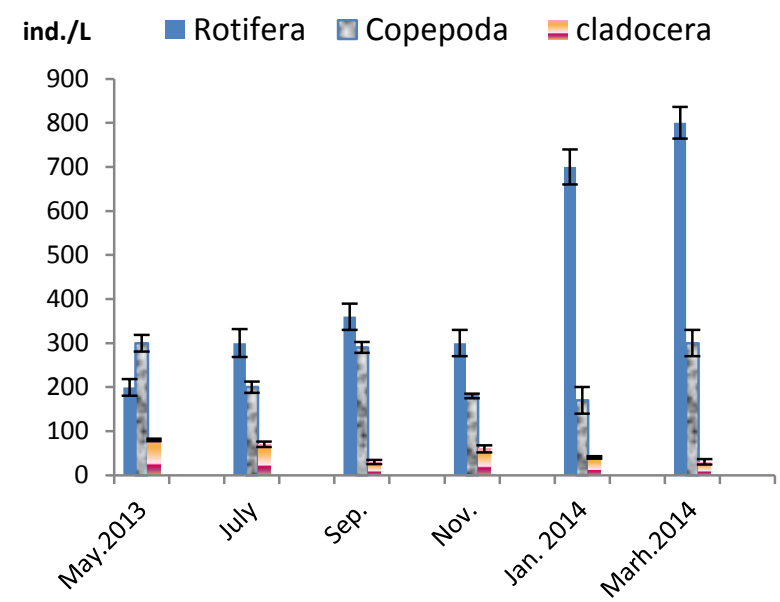

Fig. (5) Bimonthly (mean $\pm S D)$ variation in the zooplankton densities at site 4.

Table (3)

Number of taxa, number of individuals/L and diversity indices of rotifera at the different sampling sites of Al-Habbaniya Lake.

\begin{tabular}{|l|c|c|c||c|}
\hline & Site 1 & Site 2 & Site 3 & Site 4 \\
\hline \hline Number of taxa & $38^{\mathrm{a}}$ & $34^{\mathrm{a}}$ & $35^{\mathrm{a}}$ & $37^{\mathrm{a}}$ \\
\hline Number of individuals/L & $665^{\mathrm{c}}$ & $557^{\mathrm{a}}$ & $609^{\mathrm{b}}$ & $563^{\mathrm{a}}$ \\
\hline Species Richness index & $2.9^{\mathrm{a}}$ & $2.8^{\mathrm{a}}$ & $2.8^{\mathrm{a}}$ & $2.3^{\mathrm{a}}$ \\
\hline Shannon-Wiener index & $2.1^{\mathrm{a}}$ & $1.8^{\mathrm{a}}$ & $1.9^{\mathrm{a}}$ & $2^{\mathrm{a}}$ \\
\hline \hline Evenness index & $0.8^{\mathrm{a}}$ & $0.77^{\mathrm{a}}$ & $0.60^{\mathrm{b}}$ & $0.77^{\mathrm{a}}$ \\
\hline
\end{tabular}

Note: values with the same letter superscript indicate that these values were not significant among the sampling sites (Tukey HSD Test). 
Table (4)

Number of taxa, number of individuals/L and diversity indices of cladocera at the different sampling sites of Al-Habbaniya Lake.

\begin{tabular}{|l||c|c|c||c||}
\hline & Site 1 & Site 2 & Site 3 & Site 4 \\
\hline \hline Number of taxa & $10^{\mathrm{a}}$ & $8^{\mathrm{a}}$ & $9^{\mathrm{a}}$ & $9^{\mathrm{a}}$ \\
\hline Number of individuals/L & $53^{\mathrm{a}}$ & $50^{\mathrm{a}}$ & $54^{\mathrm{a}}$ & $48^{\mathrm{a}}$ \\
\hline \hline Species Richness index & $1.7^{\mathrm{a}}$ & $1.52^{\mathrm{a}}$ & $1.6^{\mathrm{a}}$ & $1.65^{\mathrm{a}}$ \\
\hline \hline Shannon-Wiener index & $1.2^{\mathrm{a}}$ & $1.1^{\mathrm{a}}$ & $1.1^{\mathrm{a}}$ & $1.2^{\mathrm{a}}$ \\
\hline Evenness index & $0.77^{\mathrm{a}}$ & $0.83^{\mathrm{a}}$ & $0.78^{\mathrm{a}}$ & $0.80^{\mathrm{a}}$ \\
\hline \hline
\end{tabular}

Note: values with the same letter superscript indicate that these values were not significant among the sampling sites (Tukey HSD Test).

Table (5)

Number of taxa, number of individuals/L and diversity indices of copepoda at the different sampling sites of Al-Habbaniya Lake.

\begin{tabular}{|l||c||c||c||c||}
\hline & Site 1 & Site 2 & Site 3 & Site 4 \\
\hline \hline Number of taxa & $7^{\mathrm{a}}$ & $8^{\mathrm{a}}$ & $6^{\mathrm{a}}$ & $6^{\mathrm{a}}$ \\
\hline \hline Number of individuals/L & $266^{\mathrm{b}}$ & $236^{\mathrm{a}}$ & $223^{\mathrm{a}}$ & $217^{\mathrm{a}}$ \\
\hline Species Richness index & $1.3^{\mathrm{a}}$ & $1.5^{\mathrm{a}}$ & $1.4^{\mathrm{a}}$ & $1.2^{\mathrm{a}}$ \\
\hline Shannon-Wiener index & $1.09^{\mathrm{a}}$ & $1.2^{\mathrm{a}}$ & $1^{\mathrm{a}}$ & $0.93^{\mathrm{a}}$ \\
\hline \hline Evenness index & $0.80^{\mathrm{a}}$ & $0.76^{\mathrm{a}}$ & $0.82^{\mathrm{a}}$ & $0.77^{\mathrm{a}}$ \\
\hline
\end{tabular}

Note: values with the same letter superscript indicate that these values were not significant among the sampling sites (Tukey HSD Test).

Moreover, the magnitude of the diversity and richness indices is sensitive both to the degree of dominance and the number of species present. Diversity is well correlated with the number of species. In the current study, high values for diversity and richness of rotifers coincided with the high number of Keratella cochlearis. While the increase in diversity and richness values for copepoda may be attributed to the high abundance of dominant taxa like copepoda nauplii.

\section{References}

[1] Dejen, E, Vijverberg, J, Nagelkerke, L, and Sibbing, F. "Temporal and spatial distribution of microcrustacean zooplankton in relation to turbidity and other environmental factors in large tropical lake (Ethiopia)" Hydrobiologia. 513:39-49, 2004.

Link:http://dx.doi.org/10.1023/B:hydr.0000 018163.60503.b8

[2] Wetzel, RG. "Limnology: Lake and river ecosystems". $3^{\text {rd }}$ ed. San Diego (CA): Academic Press, 2001.
[3] Lima, AF, Lansac-Toha, FA, Velho, LFM, Bini, LM, and Takeda, AM. "Composition and abundance of Cladocera (Crustacea) assemblages associated to Eichhornia azurea (Swartz) Kunth in the Upper Paraná River floodplain. Acta. Sci. 25 (1):41-48, 2003.

[4] Sousa, W, Attayde, JL, Da Silva, E, and Eskinazi-Santanna, EM. "The response of zooplankton assemblages to variations in the water quality of four man made lakes in semi-arid northeastern Brazil". J. Plankton Res. 30 (6):699-708, 2008.

[5] Paturej, E. "A zooplankton study of coastal lakes". Balt. Coas. Zon. 13 (2):25-32, 2009.

[6] Aoyagui, A S M, and Bonecker, CC. "Rotifers in different environments of the upper Parana river flood plain (Brazil): richness, abundance and the relationship to connectivity". Hydrobiologia. 522 (1-3): 281-290, 2004.

[7] Szczerbowski, JA, Bartel, R, and Ciepielewski, W. "Hydrological characteristics of the Dokan and Derbendikhan dam reservoirs and lakes 
Tharthar, Habbaniya and Razzazah". Arch. Pol. Fish. 9 (1):7-18, 2001.

[8] [APHA] American Public Health Association "Standard Methods for the Examination of Water and Waste water", $20^{\text {th }}$ ed. Washington (DC), 1998.

[9] Edmondson, WT. "Fresh water Biology". New York (NY): John Wiley and Sons, 1959.

[10] Pennak, RW. "Freshwater invert- ebrates of the United States, $2^{\text {nd }}$ ed. New York (NY): John Wily \& Sons, 1978.

[11] Serafim, M, Lansac-Toha, FA, Paggi, JC, Velho, FM, and Robertson, B. "Cladocera fauna composition in a river floodplain, with a new record for Brazil". Braz. J. Biol. 63 (2):349 - 356, 2003.

[12] Krebs, J R. "Ecological methodology". New York (NY): Harper Collins Publication. 1993.

[13] Magurran, A E."Measuring biolog-ical diversity". Oxford. Blackwell Science, 2004.

[14] Al-Saadi, HA. "Aquatic ecology in Iraq and its polluted sources". 26-28 Sep 1994. Proceeding of the Arabic Conference of Scientific Research and its Role in Environmental Protection from Pollution. Syria. p.59-88, 1994.

[15] Tanner, CC, Craggs, RJ, Sukias, JP, and Park, JB. "Comparison of maturation ponds and constructed wetlands as the find stage of an advanced pond system". Water Sci. Technol. 51:307-314, 2005. Link: http://www.ncbi.nlm.nih.gov/pubmed/?term $=16114699$

[16] Van Dijk, GM, and Van Zanten, B "Seasonal changes in zooplankton abundance in the lower Rhine during 19871991". Hydrobiologia. 304:29-38, 1995.

[17] Neves, IF, Rocha, O, Roche, KF, and Pinto, AA. "Zooplankton community structure of two marginal lakes of the river Cuiabá (Mato Grosso, Brazil) with a analysis of rotifera and cladocera diversity. Braz. J. Biol. 639 (2):329-343, 2003.

[18] Meshram, CB. "Zooplankton biodive rsity in relation to pollution of Lake Wadali, Amaravathi". J. Ecotoxicol. Environ. Monit.15:55-59, 2005.

[19] Webber, M, Myers, EE, Cambell, C, and Webber, D. "Phytoplankton and zooplankton as indicator of water quality in Discovery Bay Jamaica". Hydrobiologia. 545:177-193, 2005.

[20] Buyurgan, Ö, Altındağ, A, and Kaya, M. "Zooplankton community structure of Asartepe Dam Lake (Ankara, Turkey"). Turk. J. Fish. Aquat. Sci. 10:135-138, 2010.

[21] Krishnamoorthy, G, Rajalakshmi, S, and Sakthivel, D. "Diversity of zooplankton in mangrove areas of Puducherry". Indian J. Aquat. Biol. 22:45-48, 2007.

[22] Fussman, G. "The importance of crustacean zooplankton in structuring rotifer and phytoplankton communities: an enclosure study". J. Plankton. Res. 10:1897-1915, 1996.

[23] Bozkurt, A, and Guven, SE. "Zooplankton composition and distribution in vegetated and un-vegetated area in three reservoirs in Hatay, Turkey". J. Anim. Vet. Adv.8:984-994, 2009.

[24] Bass D, and Harrel, RC. "Water quality of southeast texas stream". Hydrobiologia.76:69-79, 1981.

[25] Mason, CF."Biology of freshwater pollution". $3^{\text {rd }}$ ed. Addison, Harlow: Wesley Longman, 1996.

[26] Maia-Barbosa PM, Peixoto RS, Guimarães AS. "Zooplankton in littoral waters of a tropical lake: a revisited biodiversity". Braz J Biol. 68 (4):10691078, 2008.

[27] Kuczyńska-Kippen, N, and Nagen-gast, B. "The influence of the spatial structure of hydromacro-phytes and differentiating habitat on the structure of the rotifer and cladoceran communities" Hydrobi- ologia. 559:203-21, 2006.

[28] Basavarajappa, SH, Raju, NS, Hosmani, SP, and Iranjana, SR. "Algal diversity and physico-chemical parameters in Hadhinaru Lake, Mysore, Karnataka state, India". Biosciences. 5:377-382, 2010.

[29] Rabee, AM. "The effect of Al-Tharthar Euphrates Canal on the quantitative and qualitative compostion of zooplankton in Euphrates River". J. Al-Nahrain Univ. 13 (3): 120-128, 2010. 


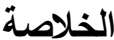

أجريت هذه الدراسة على المياه الساحلية لبحيرة الحبانية

للحصول على بيانات اساسية عن التتوع لاحيائي للعوالق

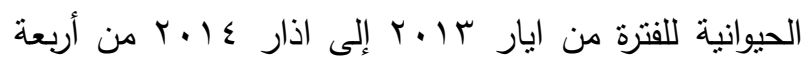
مواقع مختلفة. تم العثور على سبعة وستين وحدة تصنيفية تعود للهائمات الحيوانية في هذه البحيرة. ومن هذه الوحدات

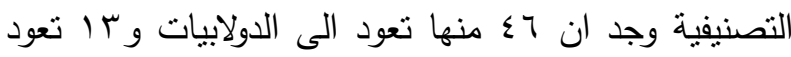

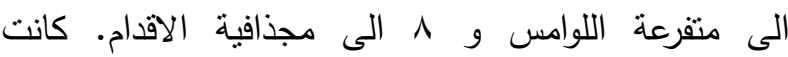

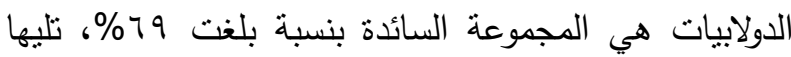
المجذافيات بنسبة ○٪\% ومن ثم متقرعة اللوامس بنسبة ؟\%\%. كانت الأنواع السائدة هي Brachionus calyciflorus و K. valga Diaphanosoma الدولابيـات، فـي حيـن كانـت فين Bosmina longirostris و هي الأنواع الاكثز سيادة من بين متفرعة اللوامس. فصليا، أثنارت نتائج

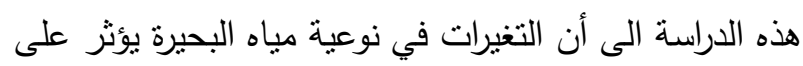

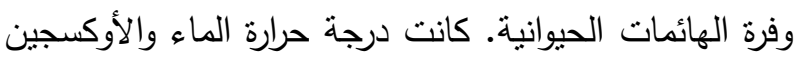
الذائب ودرجة الاس الهيدروجيني هي المتغيرات البيئية

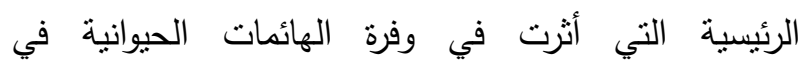

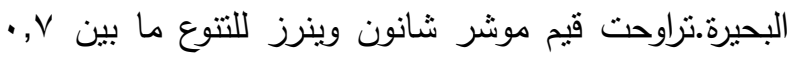

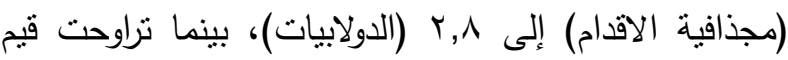

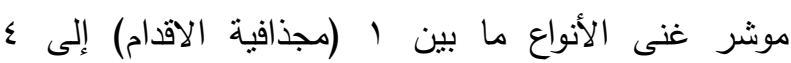

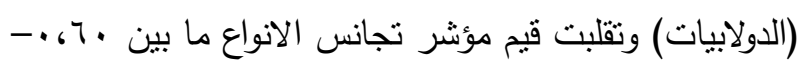

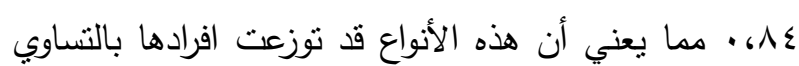

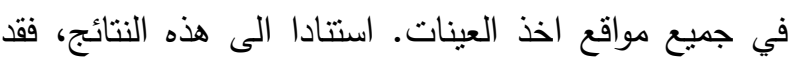

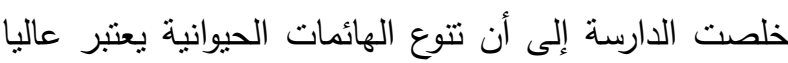

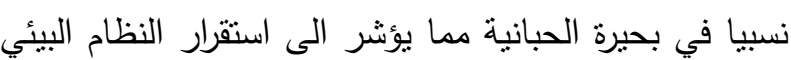
لهذه البحيرة. اما فيما يتعلق بالتتوع الاحيائي والحفاظ عليه،

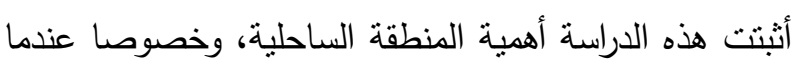

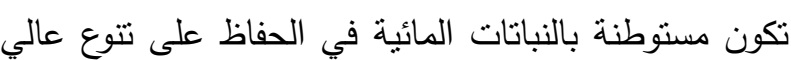
للهائمات الحيوانية. 